\title{
ULTRASTRUCTURAL ANALYSIS OF GRUNT FIN (GF) CELLS TREATED WITH RED SEA BREAM IRIDOVIRUS (RSIV; family Iridoviridae, genus Megalocytivirus) IN COMBINATIONS WITH INTERFERONS AND SPLENIC SUBSTANCES
}

\author{
Ketut Mahardika")\# and Teruo Miyazaki ${ }^{* *)}$ \\ *) Research Institute for Mariculture, Gondol - Bali \\ **) Graduate School of Bioresources, Mie University, Tsu, Mie 514-8507, Japan
}

(Received 12 February 2010; Accepted 23 April 2010)

\begin{abstract}
The genus Megalocytivirus in the family of Iridoviridae encompasses isolate of red sea bream iridovirus (RSIV). In the present study, grunt fin (GF) cells were treated with red sea bream iridovirus (RSIV) in combinations with interferons (IFNs) and splenic substances. The viral titer in the combination with primary splenic substance was higher than the other combinations of $10^{-1}$ and $10^{-2}$ diluted splenic substances, and the positive control. The viral titer was not decreased by all combinations with recombinant murine interferon- $\alpha$ (rMulFN- $\alpha$ ), recombinant murine IFN- $\beta$ (rMulFN- $\beta$ ), and recombinant feline interferon- $\omega$ ( $r F e l F N-\omega)$. Electron microscopy revealed inclusion body bearing cells (IBCs) and enlarged cells allowing virus propagation within the intracytoplasmic virus assembly site (VAS). Most were enlarged cells. These enlarged cells were divided into three cell types. Cells of Type II, which contained many mature virions within the VAS, were numerous in number in all treated cells. Cells of Type I allowing assembly of few virions and cells of Type III containing many immature viral particles were rather fewer in number. Their percentage was almost the same in all combinations with the splenic substances and IFNs. These results determined in in vitro treatment with IFNs did not prevent viral replication of RSIV, as well as the splenic substances which were derived from the RSIV-infected spleen of red sea bream did not contain any factors to disturb RSIV replication.
\end{abstract}

KEYWORDS: red sea bream, iridovirus, grunt fin, splenic substances, interferons, ultra structural analysis

\section{INTRODUCTION}

The genus Megalocytivirus in the family Iridoviridae encompasses several viral isolates such as red sea bream iridovirus (RSIV), sea bass iridovirus (SBIV), African lampeye iridovirus (ALIV), dwarf gourami iridovirus (DGIV), grouper sleepy disease iridovirus (GSDIV), Taiwan grouper iridovirus (TGIV), and infectious spleen and kidney necrosis virus (ISKNV), which are genetically identical (Chinchar et al., 2005).
In our previous study (Mahardika et al., 2004), we performed artificial infection in juvenile humpback grouper with grouper sleepy disease iridovirus (GSDIV). As a result, the mortality was lower in the groups injected with the primary filtrate than in groups receiving the $10^{-4}$ diluted inoculum. Electron microscopy revealed the presence of many unusual inclusion body-bearing cells (IBCs) containing abnormal inclusion body with a small number of

\# Corresponding author. Research Institute for Mariculture, Jl. Br. Gondol, Kec. Gerokgak, Kab. Buleleng, Kotak Pos 140, Singaraja, Bali 81101 , Indonesia. Tel.: + 6236292278

E-mail address: kmahardika@yahoo.com 
deformed virions in the former groups. This impaired virus assembly and appeared to prevent mortality in the challenged fish and was assumed to be due to an interferon-like effect of a previously unknown substance that was passed with a filtrate from the donor fish.

In order to prove this hypothesis, we performed in vitro tests using grunt fin (GF) cells and semi-purified RSIV (red sea bream iridovirus) derived from samples of infected red sea bream in combinations with the splenic substances derived from the red sea bream infected with RSIV, recombinant murine interferon- $\alpha$ (rMulFN- $\alpha$ ), recombinant murine IFN- $\beta$ ( $r$ MulFN- $\beta$ ), and recombinant feline interferon- $\omega$ ( $r$ FelFN- $\omega)$. IFN $-\alpha$ and IFN- $\beta$ are known to be potential for endogenous antiviral cytokines that suppress the replication of viruses such as murine leukaemia virus (MuLV: genus Gammaretrovirus, family Retroviridae) (Pitha et al., 1979), human herpes simplex virus type 1 (HSV-1; genus Simplexvirus, family Herpesviridae) (Härle et al., 2002; Sainz \& Halford, 2002), severe acute respiratory syndrome-associated coronavirus (SARS-CoV; genus Coronavirus, family Coronaviridae) (Sainz et al., 2004). Other type of IFN such as rFelFN- $\omega$ has clinical anti-viral activity for feline calicivirus and herpesvirus (Yamamoto et al., 1990; Uchino, 1997) as well as canine parvovirus (Uchino, 1997; Ishiwata et al., 1998) and akoya-virus infected Japanese pearl oysters Pinctada fucata martensii (Miyazaki et al., 2000). This paper describes the results of the viral titer and ultrastructural features of the RSIV-infected GF cells treated with the splenic substances and various IFNs.

\section{MATERIALS AND METHODS}

\section{Cell Culture}

GF (grunt fin) cells were used in this study. GF cells were grown in $25 \mathrm{~cm}^{2}$ cell culture flasks at $25^{\circ} \mathrm{C}$ to confluence in Eagle's minimum essential medium (MEM: Nissui, Japan) supplemented with fetal bovine serum (FBS: Sigma, USA), L-glutamine, and buffered with $\mathrm{NaHCO}$ to $\mathrm{pH}$ 7.2-7.4. For routine passage and virus inoculation, $10 \%$ and $2 \%$ FBS was added to the medium (MEM-10 and 2), respectively.

\section{Preparation of Viral Inoculum and Splenic Substances}

Semi-purified virus was prepared from the spleens of the RSIV-infected red sea bream from a mariculture farm in Mie Prefecture, Japan, likewise our previous preparation of semipurified virus (Mahardika \& Miyazaki, 2009) but with some modifications. The procedures were as follows: A total of $0.6 \mathrm{~g}$ of swollen spleens from the diseased fish was homogenized in 6 $\mathrm{mL}$ of MEM-2 containing antibiotics (penicillin $50 \mathrm{IU} \mathrm{mL}^{-1}$ and streptomycin $50 \mathrm{\mu g} \mathrm{mL}^{-1}$ ) in a glass homogenizer. The obtained homogenate was confirmed to be RSIV-positive by PCR assay described by Kurita et al. (1998). The homogenate was centrifuged (CT4D Himac, Hitachi, Japan) at 1,200 $\times \mathrm{g}$ for $15 \mathrm{~min}$. at room temperature, and the supernatant was filtered $(450 \mathrm{~nm})$. The obtained filtrate was diluted to be a final volume of $12 \mathrm{~mL}$ and ultracentrifuged (L-70 Ultracentrifuge, Beckman, USA) at $100,000 \times \mathrm{g}$ for $10 \mathrm{~min}$. at $4^{\circ} \mathrm{C}$. The supernatant was collected, filtered $(450 \mathrm{~nm})$ and used as the primary splenic substance. This substance was diluted 10 and 100 times $\left(10^{-1}\right.$ and $10^{-2}$ dilution) with MEM-2.

The sediment was resuspended in $12 \mathrm{~mL}$ of MEM-2 containing antibiotics and ultracentrifuged at $100,000 \times \mathrm{g}$ for $10 \mathrm{~min}$. at $4^{\circ} \mathrm{C}$. Then, the recovered sediment was resuspended in $5 \mathrm{~mL}$ of MEM- 2 containing antibiotics and filtered $(450 \mathrm{~nm})$. The obtained semipurified virus was used for an inoculum although, as the result, the virus concentration was decreased in number by repeated ultracentrifugation.

\section{Interferons (IFNs)}

An amount of $10^{5}$ units vial ${ }^{-1}$ of rMulFN- $\alpha$ and rMulFN- $\beta$ (PBL Biomedical Laboratories, New Brunswick, NJ.), and 10 mega units of rFelFN- $\omega$ (Toray, Japan) were dissolved with MEM.

\section{Treatments}

Two treatments were performed. The first was treatment with the splenic substances using five tubes: $0.1 \mathrm{~mL}$ of the semi-purified virus inoculum mixed into each of the four tubes containing $0.2 \mathrm{~mL}$ of different dilutions of the splenic substances (primary, 10-1 $10^{-2}$ dilution) and MEM-2 as positive control, respectively. In the fifth tube, the same volume of the primary splenic substances and MEM-2 were mixed as negative control. These five mixtures were kept at room temperature for 15 min., and inoculated into monolayer of GF cells for 1 hour at $25^{\circ} \mathrm{C}$, followed by adding the MEM- 2 to a final volume of $5 \mathrm{~mL}$. This treatment was repeated two times. 
The second was treatment with IFNs and set in two trials. First trial consisted of five tubes: $0.1 \mathrm{~mL}$ of the semi-purified virus inoculum was mixed into each of the five tubes, which contained $0.1 \mathrm{~mL}$ of different concentrations of rMulFN- $\alpha\left(10^{4}\right.$ and $10^{3}$ units $\left.\mathrm{mL}^{-1}\right)$, rMulFN- $\beta\left(10^{4}\right.$ and $10^{3}$ units $\left.\mathrm{mL}^{-1}\right)$ and MEM as control, respectively. The second trial consisting of three tubes: $0.1 \mathrm{~mL}$ of the semi-purified virus inoculum was mixed into each of the three tubes which contained $0.1 \mathrm{~mL}$ of $\mathrm{rMuIFN}-\beta\left(10^{5}\right.$ units $\left.\mathrm{mL}^{-1}\right)$, rFelFN- $\omega\left(10^{6}\right.$ units $\left.\mathrm{mL}^{-1}\right)$ and MEM as control, respectively. This second trial was repeated two times. All mixtures were kept at room temperature for $15 \mathrm{~min}$. , and inoculated into monolayer of GF cells for 1 hour at $25^{\circ} \mathrm{C}$, followed by adding the MEM- 2 to reach $5 \mathrm{~mL}$. The final concentration of both rMuIFN- $\alpha$ and rMulFN- $\beta$ was $2 \times 10^{2}$ and $2 \times 10^{1}$ units $\mathrm{mL}^{-1}$ in the first trial. In the second trial, the final concentration was $2 \times 10^{3}$ units $\mathrm{mL}^{-1}$ of rMulFN- $\beta$ and $2 \times 10^{4}$ units $\mathrm{mL}^{-1}$ of rFelFN- $\omega$.

Monolayer of GF cells were infected with semi-purified virus inoculum at a multiplicity of infection (MOI) of approximately 0.5-1. Infected cells were incubated at $25^{\circ} \mathrm{C}$. The rounded and enlarged cells were harvested by shaking the culture medium in order to separate these cells from the monolayer at 6 days post infection (p.i.). The recovered cells were used for virus titration and electron microscopy (EM).

\section{Virus Titration}

Viral titration in RSIV-infected GF cells was conducted using the $\mathrm{TCID}_{50}$ method with GF cells grown in 96-well tissue culture plates. This assay was analyzed in duplicate.

\section{Electron Microscopy}

For transmission electron microscopy, a 3.5 $\mathrm{mL}$ of harvested medium containing RSIV-infected GF cells were centrifuged at $1,200 \times \mathrm{g}$ for $10 \mathrm{~min}$. The obtained pellets were fixed with $70 \%$ Karnovsky's solution (1.6 g paraformaldehyde in $20 \mathrm{~mL}$ distilled water, $2 \mathrm{~mL}$ of $70 \%$ glutaraldehyde, $35 \mathrm{~mL}$ of $0.2 \mathrm{M}$ phosphate-buffered saline, and $13 \mathrm{~mL}$ distilled water), post-fixed in $1 \% \mathrm{OsO}_{4}$ and processed for electron microscopy, as previously described by Mahardika et al. (2008). Rounded and enlarged cells contained within $800 \mathrm{~mm}^{2}$ of the semi-thin section per sample were examined. These cells were counted at an instrument magnification of $5,000 \mathrm{X}$ to $10,000 \mathrm{X}$. The data were expressed as percentage per cells. All of obtained data were evaluated using fisher's exact test.

\section{RESULTS AND DISCUSSION}

\section{Viral Propagation in Combination With The Splenic Substances}

The viral titers in combination with the primary splenic substance were higher $\left(10^{4.93}\right.$ and $10^{5.2} \mathrm{TCID}_{50} \mathrm{~mL}^{-1}$ ) than the other combinations with splenic substances at $\left(10^{-1}\right.$ dilution: $10^{4.6}$ and $10^{4.9} \mathrm{TCID}_{50} \mathrm{~mL}^{-1}$, and $10^{-2}$ dilution: $10^{4.6}$ and $\left.10^{4.8} \mathrm{TCID}_{50} \mathrm{~mL}^{-1}\right)$, positive control $\left(10^{4.6}\right.$ and $\left.10^{4.8} \mathrm{TCID}_{50} \mathrm{~mL}^{-1}\right)$, and negative control $\left(10^{1.3}\right.$ and $\left.10^{1.7} \mathrm{~T}^{50} \mathrm{CID}_{50} \mathrm{~mL}^{-1}\right)$ in the two examinations at $6 \mathrm{~d}$ p.i. (Figure 1).

\section{Viral Propagation in Combination with IFNs}

The viral titers were $10^{4.8} \mathrm{TCID}_{50} \mathrm{~mL}^{-1}$ in both combinations with $2 \times 10^{2}$ and $2 \times 10^{1}$ units $\mathrm{mL}^{-1}$ of rMulFN- $\alpha$ at $6 \mathrm{~d}$ p.i. In the combination with 2 $\times 10^{2}$ and $2 \times 10^{1}$ units $\mathrm{mL}^{-1}$ of rMulFN- $\beta$, the viral titers were $10^{4.8}$ and $10^{4.9} \mathrm{TCID}_{50} \mathrm{~mL}^{-1}$. These viral titers were similar to the control $\left(10^{4.9} \mathrm{TCID}_{50} \mathrm{~mL}^{-1}\right)$ (Figure 2a). In combination with $2 \times 10^{3}$ units $\mathrm{mL}^{-1}$ of rMulFN- $\beta$, the viral titers were $10^{4.9}$ and $10^{5.1} \mathrm{TCID}_{50} \mathrm{~mL}^{-1}$ in the two examinations. In combination with $2 \times 10^{4}$ units $\mathrm{mL}^{-1}$ of $\mathrm{rFelFN}-\omega$, the viral titers were $10^{4.8}$ and $10^{5.1} \mathrm{TCID}_{50} \mathrm{~mL}^{-1}$ in the two examinations. These viral titers were similar to the control $\left(10^{4.9}\right.$ and $10^{5.1} \mathrm{TCID}_{50} \mathrm{~mL}^{-1}$ ) (Figure 2b).

\section{Electron Microscopic Features of GF Cells Treated with RSIV and Splenic Substances}

Electron microscopic examination of GF cells, which were treated with mixture of semipurified virus and different dilution of the splenic substances revealed IBCs and necrotic cells allowing virus propagation within the intracytoplasmic virus assembly site (VAS) at 6 d p.i. IBCs were observed a few in the number (2.1\%-5.7\%) (Table 1). Some small cells were also observed forming the intracytoplasmic VAS containing a small number of virus particles (10.8\%-12.7\%). Most were enlarged cells (83.0\%$86.6 \%$ ) and had fragmented nuclei whose components were assimilated with the cytoplasm, resulting in the disappearance of the nuclei. These cells developed intracytoplasmic VAS within which many virions were propagated. These enlarged cells were divided into three cell types. Cell type-I allowed development of 


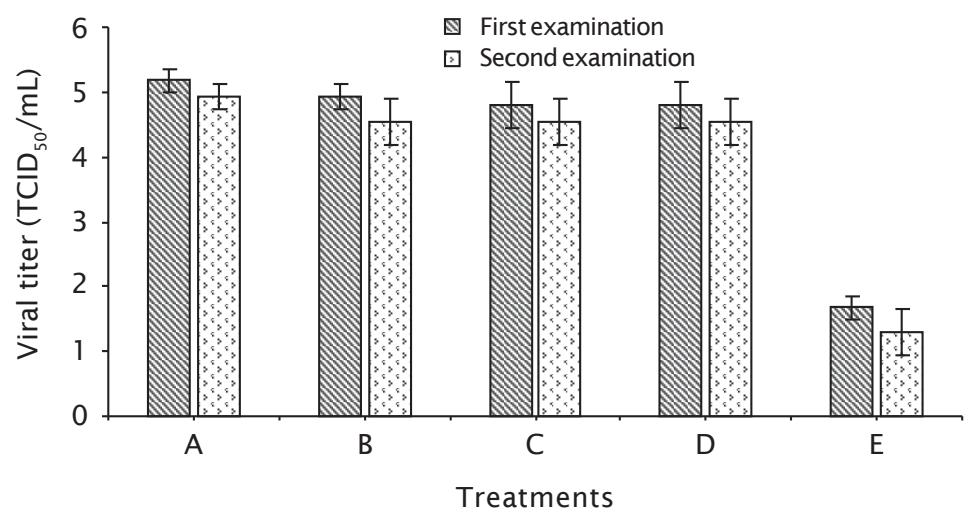

Figure 1. Viral titers of RSIV in combination with splenic substances in two examinations at $6 \mathrm{~d}$ p.i. (A) In combination with primary splenic substance, (B) In combination with $10^{-1}$ dilution of splenic substance, (C) In combination with $10^{-2}$ dilution of splenic substance, (D) Positive control, (E) Negative control. Data was analyzed in duplicate and error bars show standard deviation (SD)
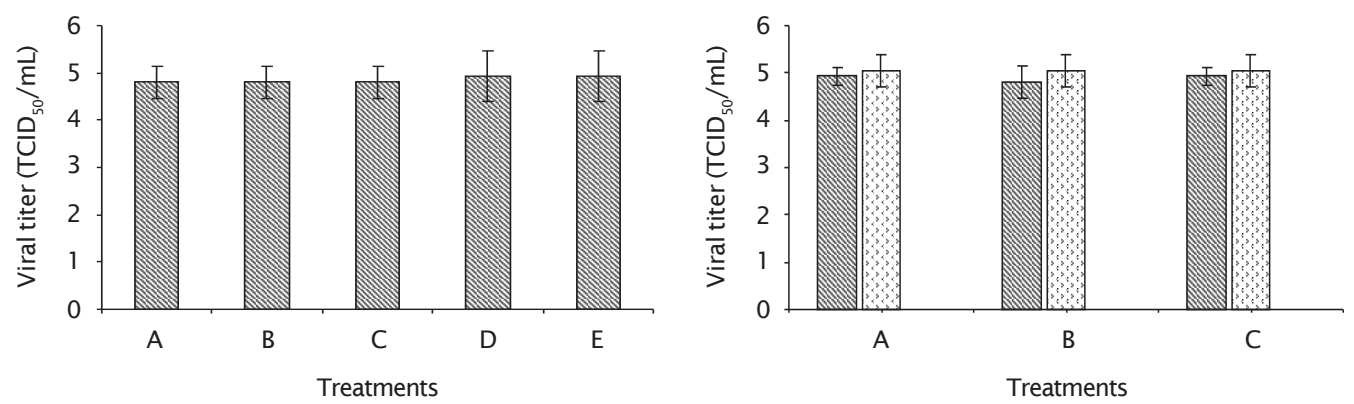

First examination Second examination

Figure 2. Viral titers of RSIV in combination with IFNs in two set trials. A: Viral titers of RSIV in combination with two different concentrations of rMulFN- $\alpha$ and $r$ MulFN- $\beta$ at $6 \mathrm{~d}$ p.i. (A) In combination with $2 \times 10^{2}$ unit $\mathrm{mL}^{-1}$ of rMulFN- $\alpha$, (B) In combination with $2 \mathrm{x}$ $10^{1}$ unit $\mathrm{mL}^{-1}$ of rMulFN- $\alpha$, (C) In combination with $2 \times 10^{2}$ unit $\mathrm{mL}^{-1}$ of rMuIFN- $\beta$, (D) In combination with $2 \times 10^{1}$ unit $\mathrm{mL}^{-1}$ of rMuIFN- $\beta$, and (E) Control. B: Viral titers of RSIV in combination with rMulFN- $\beta$ and rMulFN- $\omega$ in the two examinations at $6 \mathrm{~d}$ p.i. (A) In combination with $2 \times 10^{3}$ unit $\mathrm{mL}^{-1}$ of rMulFN- $\beta$, (B) In combination with $2 \times 10^{4}$ unit $\mathrm{mL}^{-1}$ of rMuIFN- $\omega$, and (C) Control. Data was analyzed in duplicate and error bars show standard deviation (SD)

the VAS, which showed the assembly of a few number of virions (less than 20). Cell type-II had assembled many mature virions (more than 20) within the VAS. Cell type-III contained many immature viral particles (more than 20) within the VAS. In the GF cells treated with the mixture of semi-purified virus inoculum and different dilution of the splenic substances (primary, $10^{-1}$ and $10^{-2}$ ), the percentages of cell type-I and cell type-III were $11.6 \%-18.8 \%$ and $2.9 \%$ $10.6 \%$, respectively, which were lesser than cell type-II (75.8\%-85.5\%). The percentages of these cell types were similar $(P>0.05)$ to the positive control (Table 2, Figure $3 \& 4$ ).

\section{Electron Microscopic Features of GF Cells Treated with RSIV and IFNs}

Electron microscopic examination of the GF cells treated with mixture of semi-purified virus and various IFNs focused to the enlarged cells. In combination with rMulFN- $\alpha$ and rMuIFN- 
Table 1. Electron microscopic cell count of different types of cells with virus particles derived from RSIV-infected GF cells in combination with splenic substances in vitro

\begin{tabular}{|c|c|c|c|c|}
\hline \multirow[t]{2}{*}{ Samples } & & \multicolumn{3}{|c|}{$\begin{array}{l}\text { Different types of cells with virus } \\
\text { particles }(\%)\end{array}$} \\
\hline & & Enlarged cells & IBCs & Small round cells \\
\hline \multirow{2}{*}{$\begin{array}{l}\text { In combination with primary splenic } \\
\text { substance }\end{array}$} & 1 & 83.8 & 5.4 & 10.8 \\
\hline & II & 86.6 & 2.1 & 11.3 \\
\hline \multirow{2}{*}{$\begin{array}{l}\text { In combination with } 10^{-1} \text { dilution of } \\
\text { splenic substance }\end{array}$} & 1 & 86.1 & 3.2 & 10.8 \\
\hline & II & 83.0 & 5.7 & 11.3 \\
\hline \multirow{2}{*}{$\begin{array}{l}\text { In combination with } 10^{-2} \text { dilution of } \\
\text { splenic substance }\end{array}$} & 1 & 85.2 & 3.1 & 11.7 \\
\hline & II & 85.3 & 2.9 & 11.8 \\
\hline \multirow{2}{*}{$\begin{array}{l}\text { In combination with MEM-2 (positive } \\
\text { control) }\end{array}$} & 1 & 84.1 & 3.5 & 12.4 \\
\hline & II & 83.6 & 3.6 & 12.7 \\
\hline
\end{tabular}

I: First examination, II: Second examination

Table 2. Electron microscopic cell count of different types of enlarged cells with virus particles derived from RSIV-infected GF cells in combination with splenic substances in vitro

\begin{tabular}{|c|c|c|c|c|c|c|}
\hline \multirow[b]{2}{*}{ Samples } & \multicolumn{4}{|c|}{ Different types of enlarged } & \multirow[b]{2}{*}{$\begin{array}{l}\text { Total } \\
\text { ECs } \\
(\%)\end{array}$} & \multirow{2}{*}{$\begin{array}{l}\text { Total small } \\
\text { round } \\
\text { cells with } \\
\text { virus } \\
\text { particles } \\
(\%)\end{array}$} \\
\hline & & $\begin{array}{c}\text { ECs with } \\
\text { many } \\
\text { mature } \\
\text { virions }\end{array}$ & $\begin{array}{l}\text { ECs with } \\
\text { many } \\
\text { immat ure } \\
\text { virus } \\
\text { particles }\end{array}$ & $\begin{array}{c}\text { ECs with } \\
\text { a few } \\
\text { number } \\
\text { of } \\
\text { virions }\end{array}$ & & \\
\hline \multirow{2}{*}{$\begin{array}{l}\text { In combination with primary } \\
\text { splenic substance }\end{array}$} & I & 77.6 & 9.5 & 12.9 & 87.9 & 12.1 \\
\hline & II & 75.8 & 10.6 & 13.6 & 85.7 & 14.3 \\
\hline \multirow{2}{*}{$\begin{array}{l}\text { In combination with } 10^{-1} \\
\text { dilution of splenic substance }\end{array}$} & 1 & 77.9 & 5.4 & 16.8 & 89.8 & 10.2 \\
\hline & II & 84.7 & 3.7 & 11.7 & 88.4 & 11.6 \\
\hline \multirow{2}{*}{$\begin{array}{l}\text { In combination with } 10^{-2} \\
\text { dilution of splenic substance }\end{array}$} & 1 & 76.7 & 4.5 & 18.8 & 89.3 & 10.7 \\
\hline & II & 85.5 & 2.9 & 11.6 & 89.6 & 10.4 \\
\hline \multirow{2}{*}{$\begin{array}{l}\text { In combination with MEM-2 as } \\
\text { positive control }\end{array}$} & 1 & 80.7 & 3.9 & 15.5 & 87.1 & 12.9 \\
\hline & II & 84.9 & 3.2 & 11.8 & 86.9 & 13.1 \\
\hline
\end{tabular}

IBCs were included in the enlarged cells with virus particles. I: First examination, II: Second examination

$\beta\left(2 \times 10^{2}\right.$ and $2 \times 10^{1}$ units $\left.\mathrm{mL}^{-1}\right)$, the percentages of cell type-I and cell type-III were lesser (13.5\%-14.9\% and 3.4\%-4.4\%) than cell type-II (81.0\%-82.7\%), which was almost same $(P>0.05)$ as the control (Table 3 , Figure 5 ). Some of cell type-I in combination with $2 \times 10^{2}$ units $\mathrm{mL}^{-1}$ of rMulFN- $\alpha$ contained tubule structures among immature viral particles within the VAS.
In the combinations with rMulFN- $\beta$ and rFelFN- $\omega\left(2 \times 10^{3}\right.$ and $2 \times 10^{5}$ units $\left.\mathrm{mL}^{-1}\right)$, the percentages of cell type-I and cell type-III were $17.7 \%-18.1 \%$ and $5.9 \%-6.9 \%$, respectively, which were lesser than cell type-II (75.3\%$76.0 \%)$. The percentages of these cell types were similar $(P>0.05)$ to the positive control (Table 4). 


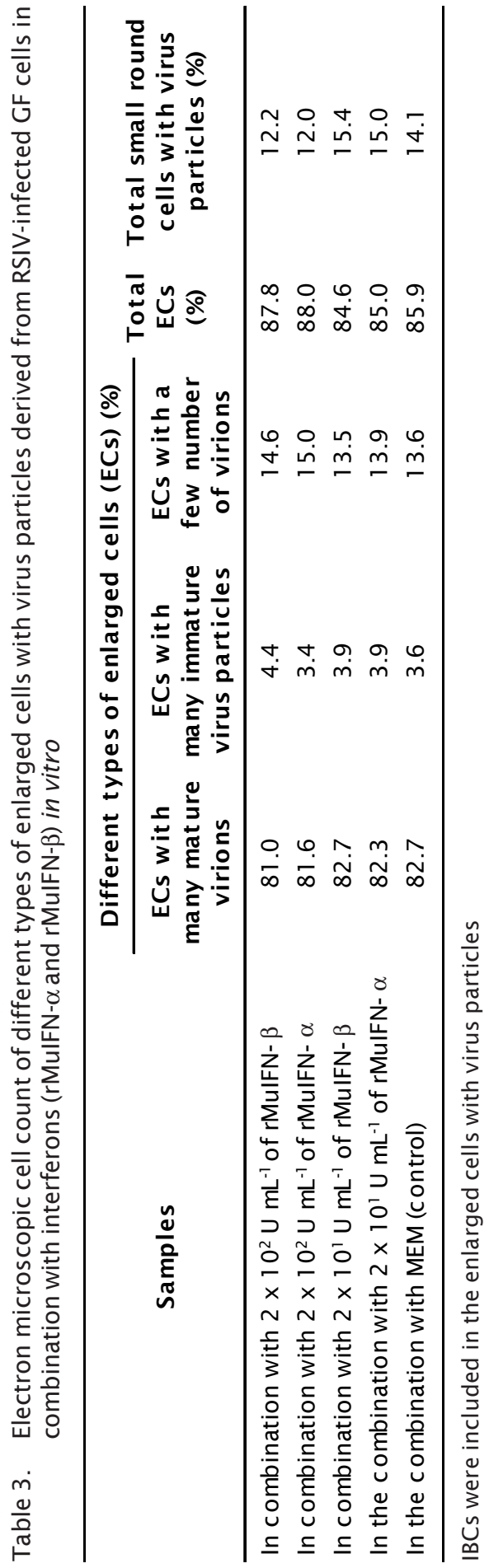



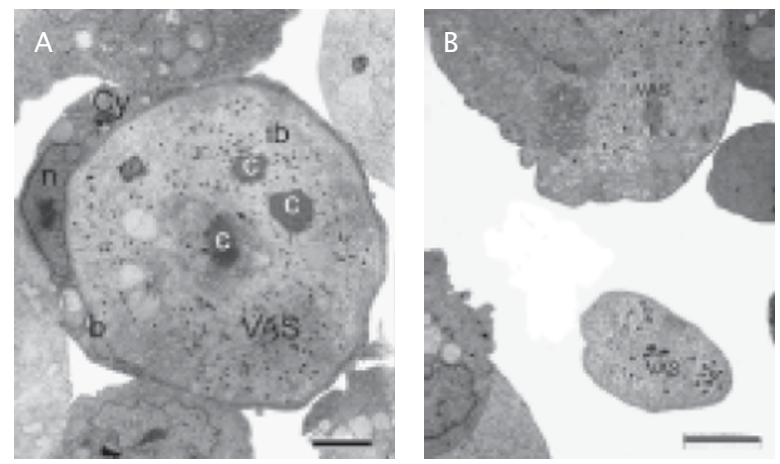

Figure 3. (A-B) Electron micrographs of IBC and cells derived from RSIV-infected GF cells in combination with splenic substances at $6 \mathrm{~d}$ p.i. (A) Mature IBC in the combination with primary splenic substance has a large inclusion body with a VAS containing a mass of coarse granules (c) and multiple virus particles (scale bar $=2,900 \mathrm{~nm}$ ). (B) Enlarged cells in combination with $10^{-2}$ dilution of splenic substance. One elarged cell (upper) has a disappearance of the nucleus and development of an intracytoplasmic VAS in which many virus particles are present. Another is small cell. This cell forms an intracytoplasmic VAS containing a small number of virus particles (scale bar $=2,400$ $\mathrm{nm})$. $\mathrm{f}$ : mass of fine granules; $\mathrm{n}$ : nucleus of host cell; VAS: virus assembly site
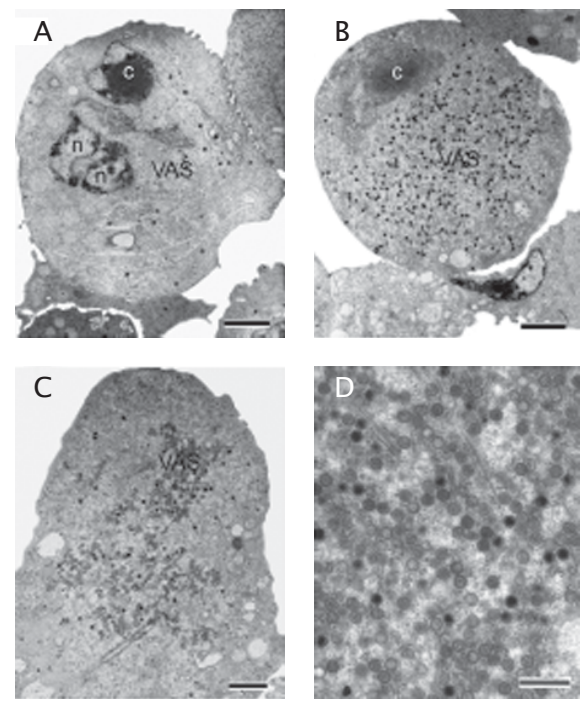

Figure 4. Electron micrographs of enlarged cells derived from RSIV-infected GF cells in the combination with splenic substances at $6 \mathrm{~d}$ p.i. (A) Cell type-I in control allows development of the VAS, which shows the assembly of a few number of virions (less than 20) (scale bar $=2,400 \mathrm{~nm}$ ). (B) Cell type-II in the combination with primary splenic substance has a disappearance of the nucleus and development of an intracytoplasmic VAS that propagation of many mature virions (more than 20) takes place (scale bar $=2,400 \mathrm{~nm}$ ). (C) Cell type-III in the combination with $10^{-1}$ dilution splenic substance has an intracytoplasmic VAS, within which many immature viral particles (more than 20) takes place (scale bar $=1,500 \mathrm{~nm}$ ). (D) Detail of an intracytoplasmic VAS in a cell type-III. Assembly of immature RSIV particles is evident within the VAS comprising granules and microfilaments. Tubular structures are also formed (scale bar $=600 \mathrm{~nm}$ ) 

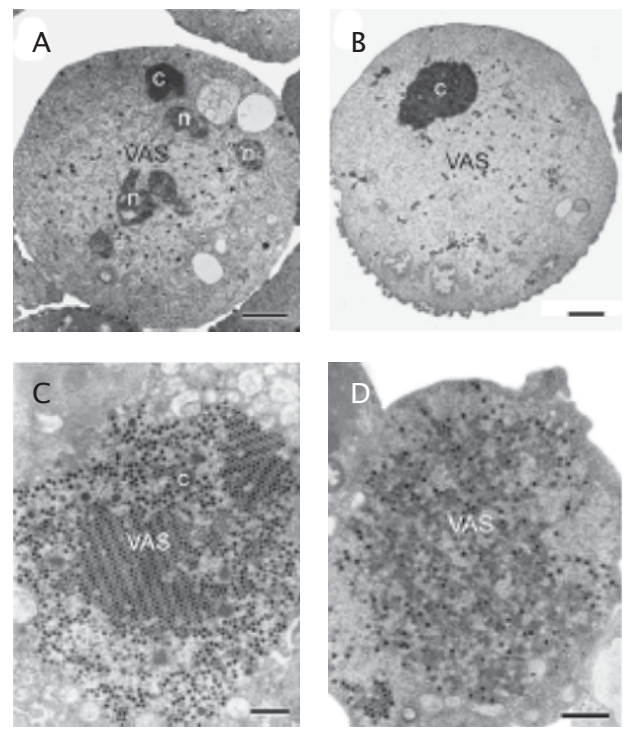

Figure 5. Electron micrographs of enlarged cells derived from RSIV-infected GF cells in combination with IFNs at $6 \mathrm{~d}$ p.i. (A) Cell type-I in combination with $2 \times 10^{2}$ unit $\mathrm{mL}^{-1}$ of rMuIFN- $\alpha$ has a developed intracytoplasmic VAS with a small number of virus particles as well as a disappearance of the nucleus (scale bar $=1,500 \mathrm{~nm}$ ). (B) Cell typeI in combination with $2 \times 10^{2}$ unit $\mathrm{mL}^{-1}$ of rMulFN- $\alpha$ has a developed intracytoplasmic VAS in which masses of coarse (c), a small number of virus particles and tubule structures takes place (scale bar $=2,000 \mathrm{~nm}$ ). (C) Cell type-II in combination with 2 $\times 10^{2}$ unit $\mathrm{mL}^{-1}$ of rMulFN- $\alpha$ has a disappearance of the nucleus and development of an intracytoplasmic VAS, within which masses of coarse (c) and fine granules, and many mature virions take place (scale bar $=1,200 \mathrm{~nm}$ ). (D) Cell type-III in combination with $2 \times 10^{1}$ unit $\mathrm{mL}^{-1}$ of rMulFN- $\alpha$ has an intracytoplasmic VAS, within which many immature viral particles take place (scale bar $=1,300 \mathrm{~nm}$ )

Table 4. Electron microscopic cell count of different types of enlarged cells with virus particles derived from RSIV-infected GF cells in combination with interferons (rMulFN- $\beta$ and rFelFN- $\omega$ ) in vitro

\begin{tabular}{|c|c|c|c|c|c|c|}
\hline \multirow[b]{2}{*}{ Samples } & \multicolumn{4}{|c|}{ Different types of enlarged } & \multirow[b]{2}{*}{$\begin{array}{l}\text { Total } \\
\text { ECs } \\
(\%)\end{array}$} & \multirow[b]{2}{*}{$\begin{array}{l}\text { Total small } \\
\text { round cells } \\
\text { with } \\
\text { virus } \\
\text { particles } \\
(\%)\end{array}$} \\
\hline & & $\begin{array}{c}\text { ECs with } \\
\text { many } \\
\text { mature } \\
\text { virions }\end{array}$ & $\begin{array}{l}\text { ECs with } \\
\text { many } \\
\text { immat ure } \\
\text { virus } \\
\text { particles }\end{array}$ & $\begin{array}{c}\text { ECs with } \\
\text { a few } \\
\text { number } \\
\text { of } \\
\text { virions }\end{array}$ & & \\
\hline \multirow{2}{*}{$\begin{array}{l}\text { In combination with } 2 \times 10^{3} \\
\text { U mL }{ }^{-1} \text { of rMulFN- } \beta\end{array}$} & 1 & 75.4 & 6.9 & 17.7 & 87.3 & 12.7 \\
\hline & II & 76.0 & 5.9 & 18.1 & 85.5 & 14.5 \\
\hline \multirow{2}{*}{$\begin{array}{l}\text { In combination with } 2 \times 10^{4} \\
\text { U mL }{ }^{-1} \text { of rMulFN- } \omega\end{array}$} & 1 & 75.3 & 6.6 & 18.1 & 86.0 & 14.0 \\
\hline & ॥ & 75.5 & 6.5 & 17.9 & 88.0 & 12.0 \\
\hline \multirow{2}{*}{$\begin{array}{l}\text { In combination with MEM } \\
\text { (c ontrol) }\end{array}$} & 1 & 77.9 & 4.6 & 17.6 & 88.5 & 11.5 \\
\hline & ॥ & 77.8 & 4.0 & 18.2 & 87.1 & 12.9 \\
\hline
\end{tabular}

IBCs were included in the enlarged cells with virus particles. I: First examination, II: Second examination 
In the present study, inoculated RSIV infected GF cells and produced cellular enlargement as a definite cytopathic effect in all combinations with the splenic substances and IFNs. The viral titer in combination with primary splenic substances was higher than the other combinations of $10^{-1}$ and $10^{-2}$ diluted splenic substances, and positive control. The viral titer was not decreased by all combinations with rMulFN- $\alpha$, rMulFN- $\beta$, and rFelFN- $\omega$. These results determined in vitro treatment with INFs did not prevent viral replication of RSIV, as well as the splenic substances which were derived from the RSIV-infected spleen of red sea bream, did not contain any factors that could disturb RSIV replication. In EM examination, IBCs seen in the GF cells that were infected with RSIV in combination with different dilutions of the splenic substances were same to those seen in the previous study (Mahardika \& Miyazaki, 2009) as well as megalocytivirus-infected cells, in vivo (Jung et al., 1997; Sudthongkong et al., 2002a; 2002b; Mahardika et al., 2004; 2008; Miyazaki, 2007). Enlarged cells were also derived from RSIV-infected GF cells and allowed assembly of viral particles in the intracytoplasmic VAS. Cells of type II, which contained many mature virions within the VAS, were numerous in number in all treated cells. Cells of type I allowing assembly of a few virions and cells of type III containing many immature viral particles were rather small in the number. Their percentages were almost the same in all combinations with the splenic substances and IFNs. IFN- $\alpha$ and IFN- $\beta$ are known to be potential as endogenous antiviral cytokines that suppress the replication of viruses (Pitha et al., 1979; Härle et al., 2002; Sainz \& Harford, 2002; Sainz et al., 2004). rFelFN- $\omega$ has clinical anti-viral activities (Yamamoto et al., 1990; Uchino, 1997; Ishiwata et al., 1998; Miyazaki et al., 2000). In the present study, there were cells with the formation of many immature viral particles within the VAS as cell type III, and cells with slight virion assembly as cell type I. However, because these cells were small in number, they did not appear to be resulted in prevention of viral replication. These results indicate that the in vitro treatment with IFNs (rMulFN- $\alpha$, rMulFN- $\beta$, and rFelFN- $\omega$ ) did not affect on the RSIV propagation in GF cells. Our in vivo study (Mahardika et al., 2004) revealed that the mortality rate in the fish injected with the primary filtrate of the spleen of GSDIV-infected grouper were lower than the fish received the
$10^{-4}$ diluted inoculum. Results of our study in vivo and in vitro resembled results of studies by Sainz \& Halford (2002) who revealed that T-cell derived gamma interferon (IFN- $\gamma$ ) inhibited the replication of herpes simplex virus type 1 (HSV-1; genus Simplexvirus, family Herpesviridae) in vivo, while in vitro, HSV-1 was highly resistant to the antiviral activity of IFN$\alpha / \beta$ or IFN $-\gamma$. Ellis (2001) reported that the cells after in vivo infection produced interferon to induce anti-viral defenses in neighboring cells, which able to lyse virally infected cells and reduce the rate of multiplication of virus within them.

It was concluded that the examined IFNs did not have antiviral efficacy to megalocytivirus in vitro. Further in vivo studies using IFNs will be needed to reveal real antiviral effects of IFNs on RSIV.

\section{REFERENCES}

Chinchar, V.G., Essbauer, S., He, J.G., Hyatt, A., Miyazaki, T., Seligy, V., \& Williams, T. 2005. Family Iridoviridae. In "Virus Taxonomy. Classification and Nomenclature of Viruses". Fauquet, C.M., Mayo, M.A., Maniloff, J., Desselberger, U., \& Ball, L.A. (Eds.). Eighth Report of the International Committee on the Taxonomy of Viruses. Academic Press, San Diego, p. 145-162.

Ellis, A.E. 2001. Innate host defense mechanisms of fish against viruses and bacteria. Dev. Comp. Immunol., 25: 827-839.

Härle, P., Cull, V., Agbaga, M-P., Silverman, R., Williams B.R.G., James, C., \& Carr, D.J.J. 2002. Differential effect of murine alpha/beta interferon transgenes on antagonization of herpes simplex virus type 1 replication. J. Virol., 76: 6,558-6,567.

Ishiwata, K., Minagawa, T., \& Kajimoto, T. 1998. Clinical effects of the recombinant feline intereron- $\omega$ on experimental parvovirus infection in beagle dogs. J. Vet. Med. Sci., 60: 911-917.

Jung, S.J., Miyazaki, T., Miyata, M., Danayadol, Y., \& Tanaka, S. 1997. Pathogenicity of iridovirus from Japan and Thailand for the red sea bream Pagrus major. Fish. Sci., 63: 735-740.

Kurita, J., Nakajima, K., Hirono, I., \& Aoki, T. 1998. Polymerase chain reaction (PCR) amplification of DNA of red sea bream iridovirus (RSIV). Fish Pathol., 33: 17-23. 
Mahardika, K., Zafran, Yamamoto, A., \& Miyazaki, T. 2004. Susceptibility of juvenile humpback grouper (Cromileptes altivelis) to grouper sleepy disease iridovirus (GSDIV). Dis. Aquat. Org., 59: 1-9.

Mahardika, K., Haryanti, Muzaki, A., \& Miyazaki, T. 2008. Histopathological and ultrastructural features of enlarged cells of humpback grouper Cromileptes altivelis challenged with Megalocytivirus (family Iridoviridae) after vaccination. Dis. Aquat. Org., 79: 163-168.

Mahardika, K. \& Miyazaki, T. 2009. Electron microscopic features of cultured grunt fin cells infected with Megalocytivirus. Aquaculture Sci., 57(1): 9-18.

Miyazaki, T., Nozawa, N., \& Kobayashi, T. 2000. Clinical trial results on the use of a recombinant feline interferon- $\omega$ to protect Japanese pearl oysters Pinctada fucata martensii from okoya-virus infection. Dis. Aquat. Org., 43: 15-26.

Miyazaki, T. 2007. Color atlas of fish histopathology, Shin-Suisan Shimbun-Sha, Tokyo, Japan, 2: 220-252.

Pitha, P.M., Wivel, N.A., Fernie, B.F., \& Harper, H.P. 1979. Effect of interferon on murine leukaemia virus infection. IV. Formation of non-infectious virus in chronically infected cells. J. gen. Virol., 42: 467-480.
Sainz, Jr.B. \& Halford, W.P. 2002. Alpha/Beta interferon and gamma interferon synergize to inhibit the replication of herpes simplex virus type 1. J. Virol., 76(22): 11541-11550.

Sainz, Jr.B., Mossel, E.C., Peters, C.J., \& Garry, R.F. 2004. Interferon-beta and interferongamma synergistically inhibit the replication of severe acute respiratory syndromeassociated coronavirus (SARS-CoV). Virology, 329: 11-17.

Sudthongkong, C., Miyata, M., \& Miyazaki, T. 2002a. Iridovirus disease in two ornamental tropical freshwater fishes: African lampeye and dwarf gourami. Dis. Aquat. Org., 48: 163-173.

Sudthongkong, C., Miyata, M., \& Miyazaki, T. $2002 \mathrm{~b}$. Viral DNA sequences of genes encoding the ATPase and the major capsid protein of tropical iridovirus isolates which are pathogenic to fishes in Japan, South China Sea and southeast Asian countries. Arch. Virol., 147: 2089-2109.

Uchino, T. 1997. Review on recombinant feline interferon in Japan. J. Anim. Clin. Med., 5: 1-10 (in Japanese).

Yamamoto, J.K., Okuma, T., \& Yanai, A. 1990. Anti feline herpesvirus and calicivirus effects of feline interferon. J. Interferon Res., 10: 114. 